http://dx.doi.org/10.12775/szhf.2015.014

\title{
DAvid Hume
}

\section{O uprzedzeniach moralnych ${ }^{*}$}

Ostatnio pojawiła się wśród nas pewna grupa ludzi, którzy pragną wyróżniać się tym, że wyśmiewają wszystko, co ludzkość uważała do tej pory za święte i godne czci ${ }^{1}$. Rozum, trzeźwość osądu, honor, przyjaźń, małżeństwo to ciągłe przedmioty ich tanich kpin. Nawet ducha wspólnoty i poważanie dla własnego kraju traktują jako chimerę i romantyczną ułudę. Gdyby plany tych anty-reformatorów miały się ziścić, wszelkie więzi społeczne musiałyby ulec rozerwaniu, aby ustąpić miejsca przyzwoleniu na pustą wesołość. Pijani hulacy zajęliby miejsce naszych braci i przyjaciól, swawolną rozrzutność zaspokajano by kosztem rzeczy wartościowych tak publicznych, jak i prywatnych, a ludzi w tak małym stopniu obchodziłoby cokolwiek poza nimi samymi, że istnienie wolnego rządu musiałoby stać się czymś całkowicie niepraktycznym i z konieczności przerodzić się w powszechne oszustwo i zepsucie.

* Podstawa przekładu: David Hume, Of Moral Prejudices, [w:] tegoż, Essays, Moral, Political, and Literary, ed. Eugene F. Miller, Liberty Fund, Inc., Indianapolis 1987. Esej ukazał się tylko w drugim tomie zbioru Essays, Moral and Political wydanym w 1742 roku. W języku polskim dostępny dotychczas w tłumaczeniu Natalii Karczewskiej w „Przeglądzie Filozoficznym”, Nowa Seria R. 20, 2011, nr 4 (80), s. 19-23. Analiza eseju, por. np.: Donald W. Livingston, Philosophical Madness and Melancholy: Hume's Pathology of Philosophy, University of Chicago Press, Chicago 1998 - przypis Marta Szymańska-Lewoszewska (dalej - MSL).

${ }^{1}$ Przykładem takich osób byli pomniejsi filozofowie (ang. minute philosophers), z poglądami których polemizował George Berkeley w dialogach Alkifron (1732). Por.: G. Berkeley, Alkifron, przeł., wstępem i przypisami opatrzył Mikołaj Olszewski, Wydawnictwo Marek Derewiecki, Kęty 2008 - przypis MSL. 
Istnieje też inne usposobienie, które możemy dostrzec u niektórych osób roszczących sobie prawo do mądrości. Choć nie jest ono tak szkodliwe jak wspomniane powyżej puste nadąsanie, to musi mieć bardzo zły wpływ na tych, którzy ją przyjmują. Mam na myśli owo śmiertelnie poważne, filozoficzne dążenie do doskonałości, które pod pretekstem poprawiania naszych przesądów i błędów sprzeniewierza się najczulszym porywom naszego serca i jeszcze bardziej pożytecznym skłonnościom i instynktom, które mogą rządzić istotą ludzką. Wśród starożytnych najbardziej znani z owego szaleństwa byli stoicy. Wielka szkoda, że w późniejszych czasach nawet bardziej godne czci osoby tak wiernie ich naśladowały. Cnotliwe i tkliwe uczucia, lub jak wolicie uprzedzenia, bardzo ucierpiały na tych poglądach. Ich miejsce zajęła ponura duma i pogarda dla tego, co ludzkie. Uznano je za najwyższą mądrość, choć w rzeczywistości nie ma nad nie większego szaleństwa. Statyliusz, namawiany przez Brutusa ${ }^{2}$, aby przyłączył się do szlachetnego towarzystwa, które zadało boski cios wolności Rzymu, odmówił stwierdzając, że wszyscy ludzie są jedynie głupcami i szaleńcami i jako tacy nie zasługują na to, aby mędrzec zaprzątał sobie nimi głowę 3 .

Światły czytelnik łatwo przypomni sobie powód, jaki podał pewien starożytny filozof, dlaczego nie może pogodzić się ze swoim bratem, który zabiegał o jego przyjaźń. Za bardzo był filozofem, aby sądzić, że pokrewieństwo wynikające z posiadania tych samych rodziców powinno mieć jakikolwiek wpływ na racjonalny umysł i wyraził swoją opinię w taki sposób, że nie byłoby rzeczą stosowną jej powtarzać ${ }^{4}$. Gdy twój przyjaciel cierpi, powiada Epiktet, możesz udawać, że mu współczujesz, jeśli przyniesie mu to ulgę. Uważaj jednak, by nie dopuścić, aby prawdziwe współczucie zawładnęło twym sercem, lub zakłóciło spokój ducha, który jest najwyższą mądrością

\footnotetext{
${ }^{2}$ Brutus, Marcus Iunius Brutus, Quintus Serviulius Caepio Brutus, (85-42 r. p.n.e.) - polityk, retor i filozof rzymski - przypis MSL.

${ }^{3}$ Zob.: Plutarch, The Life of Brutus, [w:] Plutarch, The Parallel Lives, 11 vols., transl. by Bernadotte Perrin, Loeb Classical Library, Cambridge, MA and London, 1918, t. VI, \$12, s. 151, dostępne na: http://penelope.uchicago.edu/Thayer/E/Roman/Texts/Plutarch/Lives/Brutus*. html [31.03.2015]. Według przekazu Plutarcha Brutus utrzymywał spisek przeciwko Cezarowi w tajemnicy przed swym przyjacielem, epikurejczykiem Statyliuszem, ponieważ, kiedy wcześniej w trakcie dyskusji pośrednio poddał go próbie, ten odpowiedział mu w sposób opisany przez Hume’a - przypis E. F. Miller.

${ }^{4}$ Nie udało się zidentyfikować starożytnego filozofa, do którego odwołuje się Hume ani źródła przytoczonej przez niego historii - przypis E. F. Miller.

${ }^{5}$ Por.: „Ilekroć widzisz, że ktoś we łzach i smutku tonie, ponieważ jego dziecko udało się w podróż, albo że stracił swój dobytek, nie daj się owładnąć wyobrażeniu, jakoby te rzeczy
} 
Gdy przyjaciele zapytali Diogenesa, co ma się stać z nim po jego śmierci, powiedział: „Jak to, co? „Porzućcie mnie na polu”. - „Na pastwę ptakom i dzikim zwierzętom?” - „Bynajmniej - odparł - połóżcie przy mnie kij, a będę je odpędzał”. - „Jakże to uczynisz, skoro nic nie będziesz czuł? pytali dalej. - „Cóż mi więc zaszkodzi, że dzikie zwierzęta mnie rozszarpią, skoro nie będę czuł?” - „Przecież nie będziesz posiadał ani zmysłów, ani siły, aby go użyć”, „Kiedy zatem zwierzę będzie chciało mnie pożreć - odkrzyknął im na to - to czy tym bardziej to odczuję?" powiedzi tego filozofa, która w lepszy sposób oddawałaby tak żywość, jak i zaciekłość jego usposobienia?

Jakże różne od powyższych są maksymy, którymi kieruje się Eugeniusz! W młodości niestrudzenie oddawał się studiowaniu filozofii i nic nie było go w stanie od niej odciągnąć prócz okazji służenia pomocą swoim przyjaciołom i sprawiania przyjemności wartościowym ludziom. Gdy miał około lat trzydziestu, postanowił zakończyć swobodne życie kawalera, (które w przeciwnym wypadku stałoby się jego udziałem), wziąwszy pod uwagę, że jest ostatnim przedstawicielem pewnego starożytnego rodu, który wygasłby, gdyby umarł bezdzietnie. Na swą małżonkę wybrał piękną i cnotliwą Emirę. Przez wiele lat była ona radością jego życia, uczyniła go ojcem kilkorga dzieci i ostatecznie oddała ducha. Nic nie mogło dać mu oparcia w ogromnym cierpieniu, jak tylko pociecha z dzieci, które teraz, w związku ze śmiercią ich matki stały się mu jeszcze droższe. W szczególności jedna z córek jest jego oczkiem w głowie i skrytą radością duszy, jako że jej rysy, posta-

zewnętrzne były źródłem jego nieszczęścia, ale natychmiast tę myśl przyzwij sobie na pomoc: 'To przecież nie samo wydarzenie go gnębi (kogo innego przecież ono nie gnębi), ale mniemanie, jakie ten człowiek ma o nim.' Wszelako ani się waż zwracać do niego ze słowami pociechy, a już tym bardziej - współczująco z nim razem jęczeć, co więcej, strzeż się, żebyś nawet w duchu nie jęczał”. Epiktet, Encheiridion, \$16, [w:] Epiktet, Diatryby; Encheiridion z dodaniem Fragmentów oraz Gnomologium Epiktetowego, z jęz. grec. przeł. i oprac. Leon Joachimowicz, PWN, Warszawa 1961, s. 462-463 - przypis MSL.

${ }^{6}$ Marcus Tullius Cicero, Rozmowy Tuskulańskie, fragm. 1.104, [w:] Marcus Tullius Cicero, Księgi akademickie; O najwyższym dobru i złu; Paradoksy stoików; Rozmowy Tuskulańskie, przeł. Józef Śmigaj, koment. opatrzył Kazimierz Leśniak, PWN, Warszawa 1961, t. 3, s. 541 przypis MSL.

${ }^{7}$ Diogenes z Synopy (400?-325? p.n.e.) był założycielem filozoficznej szkoły cyników, która upatrywała szczęście w ascetycznym życiu polegającym na zaspokajaniu jedynie nielicznych potrzeb naturalnych i otwartej pogardzie wobec rzeczy, które tradycyjnie uznawano za pożądane. Hume odwołuje się tu do słów Diogenesa ujętych przez Cycerona w Rozmowach Tuskulańskich fragm. 1.104 - przypis E. F. Miller. 
wa i głos w każdej chwili przypominają czułe wspomnienia jego małżonki wypełniając jego oczy łzami. Skrywa on ową stronniczość jak tylko może i nikt poza jego bliskimi przyjaciółmi o niej nie wie. Tylko przed nimi odkrywa swe czułe serce; jego filozoficzne usposobienie nie jest także na tyle sztuczne, aby nie mógł określić tego mianem słabości. Oni wiedzą, że urodziny Emiry, które za jej życia były powodem radości i świętowania, teraz wita ze łzami w oczach, podobnie jak pamięć o miłych i czułych chwilach. Wiedzą też, że z największą troską pielęgnuje w pamięci jej obraz, a także, że posiada jej miniaturowy portret, który zawsze nosi na sercu, jak również i o tym, że w swej ostatniej woli zapisał, aby bez względu na to, w jakiej części świata dosięgłaby go śmierć, jego ciało zostało sprowadzone i złożone w tym samym grobie co ona, a ich miłość i wzajemne szczęście uczczono w epitafium, które w tym celu wcześniej ułożył ${ }^{8}$.

Kilka lat temu otrzymałem list od pewnego przyjaciela odbywającego zagraniczne podróże, który chcę tutaj zacytować. Zawiera on przykład takiej filozoficznej postawy, dość wyjątkowej, jak sądzę, i może służyć jako przykład, aby poprzez przesadne dążenie do szczęścia i doskonałości nie oddalać się za bardzo od przyjętych zasad postępowania i zachowania. Zapewniono mnie, że ta historia jest prawdziwa.

Panie!

Wiem, że bardziej interesują Cię historie ludzi niż budynków i bardziej pragniesz poznać czyjeś osobiste historie niż zajmować się sprawami publicznymi. Z tego powodu pomyślałem, że poniższa historia, która jest powszechnym tematem rozmów w tym mieście, będzie dla Ciebie miłą rozrywką. Pewna młoda dama, dobrze urodzona i posiadająca majątek, który pozostawiono do jej całkowitej dyspozycji, długo trwała w postanowieniu prowadzenia samotnego życia pomimo kilku korzystnych propozycji, jakie

\footnotetext{
${ }^{8}$ Eugeniusza, którego życiorys zgadzałby się z podanymi szczegółami, nie udało się odnaleźć ani pośród osób istniejących rzeczywiście, ani postaci fikcyjnych. Najprawdopodobniej przytoczona historia oraz list zostały wymyślone przez Hume’a. Eugeniusz (dosł. „dobrze urodzony”, „dobry duch”, „o dobrych skłonnościach”, „dobrze usposobiony”) może uosabiać życie filozoficzne, w którym postępuje się odpowiednio za głosem serca. Imię 'Eugeniusz’ nadał jednemu z uczestników rozmowy Joseph Addison w Dialogach o użyteczności starożytnych medali (tłum. MSL) [Dialogues upon the Usefulness of Ancient Medals (1721)]. Imię to nosi także jedna z postaci w powieści Laurence’a Sterne'a Tristram Shandy (1760-67) [tłum. w j. pol.: L. Sterne, Życie i myśli J. W. Pana Tristrama Shandy, t. 1-2, przeł. Krystyna Tarnowska, przejrzał i posł. opatrzył Witold Chwalewik „Czytelnik”, Warszawa 1974] - przypis E. F. Miller.
} 
jej składano. Widząc wiele nieszczęśliwych małżeństw wśród swoich znajomych, a także słysząc jak jej przyjaciółki skarżą się na tyranię, niestałość, zazdrość oraz obojętność swych mężów, była zdecydowana wytrwać w swym postanowieniu. Jako kobieta o silnym charakterze i myśląca w niecodzienny sposób nie miała trudności ani ze sformułowaniem tego postanowienia, ani z wytrwaniem w nim. Nie mogła także podejrzewać samej siebie o taką słabość, by jakaś pokusa miała ją kiedykolwiek od niego odwieść. Niemniej jednak poczuła mocne pragnienie posiadania syna, którego wychowanie postanowiła uczynić główną troską swego życia. Miało to zastąpić wszystkie inne uczucia, których zdecydowała się na zawsze wyrzec. Zadała sobie w swej filozofii niezwykle wiele trudu, aby nie dostrzegać żadnej sprzeczności pomiędzy takim pragnieniem i jej wcześniejszym postanowieniem. $Z$ wielkim namysłem rozglądała się, chcąc znaleźć pośród znajomych mężczyzn jednego, którego charakter i osobowość, by jej odpowiadały. Nikt jednak nie mógł sprostać jej oczekiwaniom. Z czasem, gdy pewnego wieczoru odwiedziła teatr, zauważyła na parterze młodego mężczyznę o ujmującej powierzchowności i skromnym zachowaniu; poczuła wówczas w sobie taką skłonność ku niemu, że odżyły w niej nadzieje, iż on właśnie jest tą osobą, której tak długo bez powodzenia szukała. Od razu posłała do niego swego służącego, żądając spotkania z nim w swej posiadłości nazajutrz rano. Młodzieniec był uradowany wiadomością i nie posiadał się z zadowolenia, otrzymawszy takie wyróżnienie od damy o tak pięknej urodzie, reputacji i takich zaletach. Był też więc mocno zawiedziony, gdy zastał kobietę, która nie chciała pozwolić mu na żadną swobodę i w całym swym sztywnym zachowaniem zmusiła go do tego, aby w rozmowie zachował granice rozumności. Wydawało się jednak, że miała ochotę się z nim zaprzyjaźnić. Powiedziała mu, że gdy tylko znajdzie dla niej wolną chwilę, jego towarzystwo będzie zawsze mile widziane. Jej piękno i błyskotliwość tak go uderzyły, że nie potrzebował większej zachęty, aby ponowić swoją wizytę. Gdyby został pozbawiony jej towarzystwa, byłby nieszczęśliwy. Każda rozmowa służyła tylko jednemu: podsycaniu jego namiętności i dawała mu kolejną okazję, by mógł podziwiać jej osobowość i rozum, jak również docenić, jakie spotkało go szczęście. Niepokoił się jednak na myśl o różnicy w ich urodzeniu i majątku. Jego wątpliwości nie zmniejszały się też, kiedy zastanawiał się nad niezwykłym sposobem, w jaki została nawiązana ich znajomość. Tymczasem nasza filozoficzna bohaterka odkryła, że cechy charakteru jej kochanka nie szły w parze z jego powierzchownością. Sądząc, że nie będzie już okazji do dalszych poszukiwań, w stosownym momencie przedstawiła mu cały swój zamiar. Ich 
kontakty trwały przez jakiś czas, aż do momentu, kiedy nie spełniło się jej życzenie. Była teraz matką chłopca, który miał być przedmiotem jej troski i uwagi. Z przyjemnością kontynuowałaby przyjaźń z jego ojcem. Skoro jednak odkryła, że jest on zbyt namiętnym kochankiem, aby zachowywać granice przyjaźni, została zmuszona samej sobie zadać gwałt. Wysłała mu list, w którym zobowiązała się do wypłacania mu do końca życia tysiąc koron rocznie, życząc sobie przy tym, aby już nigdy więcej się nie spotykali i aby zapomniał, o ile to możliwe, o wszystkich dawnych względach i wzajemnej poufałości. Ta wiadomość poraziła go niczym piorun. Gdy na próżno próbował przezwyciężyć postanowienie kobiety, zdecydował wykorzystać jej dziwactwo przeciwko niej samej. Wniósł przeciwko niej pozew sądowy do parlamentu paryskiego, roszcząc sobie prawo decydowania o wykształceniu swego syna zgodnie $\mathrm{z}$ własną wolą, co w takich przypadkach przewidywało prawo. Ona z kolei przedstawiła ich wyraźną umowę zanim zaczęli współżyć i starała się dowodzić, że on zrzekł się wszystkich praw do potomstwa, które mogłoby się pojawić w wyniku ich zbliżenia. Jeszcze nie wiadomo, co sąd orzeknie w tym niezwykłym przypadku, który zadziwia w równym stopniu wszystkich prawników, jak i filozofów. Kiedy tylko dojdą do jakiegoś rozwiązania, poinformuję Cię o nim i wykorzystam każdą okazję, aby zaświadczyć o tym własnym podpisem, tak jak czynię to teraz.

Pański najbardziej uniżony sługa.

Przełożyła Marta Szymańska-Lewoszewska 